\title{
Arbuscular mycorrhizal fungi abundance was sensitive to nitrogen addition but diversity was sensitive to phosphorus addition in karst ecosystems
}

\author{
Dan Xiao ${ }^{1,2,3} \cdot$ Rongxiao Che ${ }^{4}$ Xin $\mathrm{Liu}^{1,2,3} \cdot$ Yongjun Tan ${ }^{1,3} \cdot$ Rong Yang ${ }^{1,2,3} \cdot$ Wei Zhang ${ }^{1,2} \cdot$ Xunyang He $^{1,2}$. \\ Zhihong $\mathrm{Xu}^{5} \cdot$ Kelin Wang ${ }^{1,2}$
}

Received: 30 November 2018 / Revised: 26 March 2019 / Accepted: 2 April 2019

(C) Springer-Verlag GmbH Germany, part of Springer Nature 2019

\begin{abstract}
Determining the effects of nitrogen $(\mathrm{N})$ and phosphorus $(\mathrm{P})$ application on arbuscular mycorrhizal fungi (AMF) communities is important for predicting AMF responses to nutrient deposition. The AMF parameters and soil properties were monitored in karst grassland after 2 years of $\mathrm{N}$ and $\mathrm{P}$ addition. Then, $\mathrm{AMF}$ abundance, diversity, and community composition significantly differed between seasons. AMF abundance was higher in July (summer) than in December (winter), whereas richness and Chao1 estimator values showed the opposite results. The numbers of the genera Funneliformis and Sclerocystis were significantly more abundant in December, but the proportions of Scutellospora, Redeckera, and Diversispora were significantly higher in July. N and NP treatments significantly increased AMF abundance; richness and Chaol values in the P treatment were significantly higher than those of the control in July. AMF community composition changed substantially between December and July but did not respond to fertilization. AMF abundance was significantly correlated with total $\mathrm{N}$ (TN), while AMF richness was also

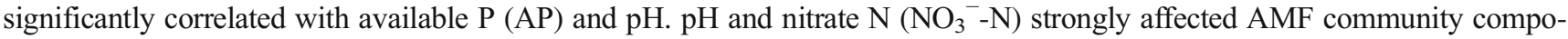
sition. These results suggested that $\mathrm{P}$ became more limiting with $\mathrm{N}$ fertilization, $\mathrm{AMF}$ investment increased access to more $\mathrm{P}$, and richness was lower when certain AMF taxa (Diversisporales) increased in abundance during the growing season and under more $\mathrm{P}$-limiting conditions. These results also suggested that $\mathrm{N}$ and $\mathrm{P}$ addition have specifically different effects on AMF abundance and diversity, and consequently potential effect on long-term vegetation composition and productivity.
\end{abstract}

Keywords Mycorrhiza $\cdot$ Hiseq sequencing $\cdot$ Grassland $\cdot \mathrm{N}$ fertilizer $\cdot \mathrm{P}$ fertilizer $\cdot$ Fragile ecosystems

Electronic supplementary material The online version of this article (https://doi.org/10.1007/s00374-019-01362-x) contains supplementary material, which is available to authorized users.

Wei Zhang

zhangw@isa.ac.cn

Kelin Wang

kelin@isa.ac.cn

1 Key Laboratory of Agro-Ecological Processes in Subtropical Region, Institute of Subtropical Agriculture, Chinese Academy of Sciences, Changsha 410125, China

2 Huanjiang Observation and Research Station for Karst Ecosystems, Chinese Academy of Sciences, Huanjiang 547100, China

3 University of Chinese Academy of Sciences, Beijing 100039, China

4 Institute of International Rivers and Eco-Security, Yunnan University, Kunming 650091, China

5 Environmental Futures Research Institute, School of Environment and Science, Griffith University, Brisbane 4111, Australia

\section{Introduction}

Global atmospheric $\mathrm{N}$ deposition has substantially increased due to human activity (Camenzind et al. 2016; Galloway et al. 2004). Recent findings indicate that $P$ levels under $N$ enrichment are insufficient to balance increased $\mathrm{N}$ deposition, leading to severe P deficiency (Marklein and Houlton 2012). The availability of $\mathrm{N}$ and $\mathrm{P}$, individually or in combination, has been widely recognized as a predominant factor limiting primary productivity in terrestrial ecosystems (Liu et al. 2012; Vitousek et al. 2010). Arbuscular mycorrhizal fungi (AMF) are of great ecological significance because they form obligate symbioses that provide $\mathrm{P}$ and $\mathrm{N}$ to $70-90 \%$ of plant species (Taylor et al. 2017). AMF can increase $P$ acquisition, water uptake, and soil stability (Rillig 2004), and they are sensitive to $\mathrm{N}$ and $\mathrm{P}$ input (He et al. 2016). Cozzolino et al. (2010) reported that the addition of small quantities of $\mathrm{P}$ positively 
influences AMF colonization when available soil $\mathrm{P}$ is low. $\mathrm{N}$ and $\mathrm{P}$ inputs are widely believed to affect (positively, negatively, or non-significantly) AMF abundance, diversity, and community composition by changing the soil microenvironment (Camenzind et al. 2014; Cozzolino et al. 2010; Xie et al. 2014; Zheng et al. 2014). However, N and P inputs in varied ecosystems with either nutrient saturation or limitation affect AMF communities differently (Delavaux et al. 2017; Matson et al. 1999). Therefore, the determination of the individual and combined effects of $\mathrm{N}$ and $\mathrm{P}$ on $\mathrm{AMF}$ communities is important for predicting AMF feedback to global $\mathrm{N}$ deposition, and also to improve our understanding of the effects AMF have on $\mathrm{N}$ and $\mathrm{P}$ processes.

$\mathrm{N}$ and $\mathrm{P}$ application might affect soil AMF abundance, diversity, and community composition in a number of ways. First, $\mathrm{N}$ and $\mathrm{P}$ addition may temporarily increase soil acidity, leading to increased losses of cations and decreased availability of $\mathrm{P}$, thus indirectly affecting AMF abundance and community composition. Some AMF species are only found in acidic or alkaline soils, but others can inhabit both soils (Porter et al. 1987). Liu et al. (2013) found no significant correlation between $\mathrm{N}$ addition and soil $\mathrm{pH}$ in an $\mathrm{N}$ saturated system. Therefore, in N-limited or alkaline soil, soil $\mathrm{pH}$ would be sensitive to $\mathrm{N}$ and $\mathrm{P}$ addition, thereby affecting AMF community composition (Nottingham et al. 2017). Other studies have shown that $\mathrm{N}$ and $\mathrm{P}$ applications can markedly change $\mathrm{N}$ and $\mathrm{P}$ availability (e.g., $\mathrm{NH}_{4}{ }^{+}$or $\mathrm{NO}_{3}{ }^{-}$) (Egerton-Warburton et al. 2007; Wang et al. 2008). Plants invest less $\mathrm{C}$ to $\mathrm{AMF}$ in exchange for nutrients when the availability of $\mathrm{N}$ or $\mathrm{P}$ in the soil is sufficient for plant growth. Conversely, if $\mathrm{N}$ or $\mathrm{P}$ availability is limited, increased AMF abundance is expected (Johnson et al. 2003; Treseder 2004). Moreover, the season is an important factor affecting AMF community composition (Bohrer et al. 2004; Dumbrell et al. 2011; Santos-Gonzalez et al. 2007). Changes in temperature and moisture affect $\mathrm{N}$ and $\mathrm{P}$ availability, thereby altering AMF community composition and diversity (Dumbrell et al. 2011). Furthermore, the seasonal dynamics of AMF colonies within plant roots occurs in response to plant phenology (Bohrer et al. 2004). Higher AMF abundance coincides with the growing season when plant demand for additional $\mathrm{N}$ and $\mathrm{P}$ increases. To date, the effects of $\mathrm{N}$ and $\mathrm{P}$ applications on soil AMF community compositions have rarely been documented in different seasons and have focused primarily on AMF abundance (Bhadalung et al. 2005; Camenzind et al. 2014; Gavito et al. 2003; Liu et al. 2017; Johnson et al. 2003). With the increasing of $\mathrm{N}$ deposition, $\mathrm{N}$ addition may enhance $\mathrm{P}$ demand. AMF community compositions may respond differently to $\mathrm{N}$ and $\mathrm{P}$ addition. Therefore, it is necessary to determine changes in AMF community composition in response to $\mathrm{N}$ and $\mathrm{P}$ application in different seasons and across varied environmental conditions.
The effects of $\mathrm{N}$ and $\mathrm{P}$ application on AMF abundance and community depend on plant communities (Majewska et al. 2018; Turrini et al. 2017), soil type (Montiel-Rozas et al. 2017), and soil properties (Treseder and Allen 2002) in different ecosystems. Thus far, studies have generally been conducted on fertilization for more than 2 years (Bhadalung et al. 2005; Huang et al. 2016; Xue et al. 2017). However, short-term studies for less than 2 years are important because they can provide insights into the adaptation of soil microclimate and nutrients. In addition, $\mathrm{P}$ does not accumulate at the same rate as $\mathrm{N}$ owing to the lack of biological fixation and low atmospheric deposition (Huang et al. 2016; Walker and Syers 1976). Many experiments use the same $\mathrm{N}$ and $\mathrm{P}$ addition rates (Liu et al. 2013) or an $\mathrm{N}$ deposition rate close to atmospheric levels with low $\mathrm{P}$ addition (Camenzind et al. 2014; Tischer et al. 2015). It remains unclear how high $\mathrm{N}$ input and medium $\mathrm{P}$ input, or the interaction thereof, would influence AMF abundance, diversity, and community composition when $\mathrm{N}$ deposition dramatically increases, especially in grassland soils. Moreover, studies on the responses of AMF to $\mathrm{N}$ and $\mathrm{P}$ addition have been restricted to boreal, temperate, and tropical ecosystems thus far (Camenzind et al. 2016; Delavaux et al. 2017), and the effects of $\mathrm{N}$ and $\mathrm{P}$ fertilization on AMF are unknown in karst regions.

Karst terrain typically develops on carbonate rocks (e.g., limestone, dolomite, or marble) and accounts for $15 \%$ of Earth's land surface. Furthermore, the world's largest karst regions occur in southwest China, occupying about $36 \%$ of the total land (Jiang et al. 2014). This region is characterized by poor stability, susceptibility to land degradation due to human disturbances, low-nutrient levels, and a decreased ability of self-recovery (Liu et al. 2015). This area experienced severe deforestation and agricultural expansion from 1949 to the end of the 1990s. Since the end of the 1990s, China launched the "Grain-for-Green" project, and most former croplands have been abandoned and transformed into woodland or grassland (Liu and Diamond 2005). The postagricultural succession of grassland has been allowed to recover naturally for $>20$ years. A large portion of soil $\mathrm{N}$ was lost during the cultivation period and was subjected to $\mathrm{N}$ limited conditions in the early-stage grasslands of the karst region in southwest China (Zhang et al. 2015). Moreover, Niinemets and Kull (2005) reported a deficiency in bioavailable $\mathrm{P}$ rather than $\mathrm{N}$ in calcareous soils due to high $\mathrm{pH}$. $\mathrm{P}$ availability may be another key factor that affects vegetation recovery in karst terrains (Hofmeister et al. 2002). Niinemets and Kull (2005) suggested that N and P co-limitations are common in diverse calcareous grasslands. AMF have been reported to play an important role in karst ecosystem protection and rocky desertification restoration (Wei 2012; Zhang et al. 2014). Glomus was found to be the dominant genus in a karst area of south China, and it should be a candidate for ecological restoration in such areas (Wei 2012). Liang et al. 
(2015) found that karst soil of southwest China harbors abundant AMF resources and that AMF richness is closely correlated with plant richness, soil organic $\mathrm{C}$, soil available $\mathrm{P}$, and $\mathrm{pH}$ in this region. AMF richness in grasslands has been found to be higher than that in a shrub, secondary, and primary forest during vegetation restoration in degraded karst ecosystems (Liang et al. 2015). Selected AMF species might form stable cooperative relationships with plant species (Kiers et al. 2011). In addition, the higher light incidence in grasslands can improve the photosynthetic capacity and increase carbohydrates exported to roots for AMF. AMF diversity may play an important role in the post-agricultural succession of the grasslands. However, the consequences of nutrient deposition on AMF abundance, diversity, and community composition are not known for nutrient-limited grassland environments of karst regions.

A 2-year $\mathrm{N}$ and $\mathrm{P}$ fertilization experiment was performed in karst grassland to examine the effects of nutrient deposition on AMF abundance, diversity, and community composition. We hypothesized that the application of $\mathrm{N}$ and $\mathrm{P}$ might indirectly affect the AMF abundance, diversity, and community composition by changing soil $\mathrm{pH}$ and $\mathrm{N}$ and $\mathrm{P}$ availability. Therefore, we measured seasonal changes in AMF abundance, diversity, and community composition, as well as associated environmental factors (e.g., $\mathrm{pH}, \mathrm{NH}_{4}{ }^{+}-\mathrm{N}$, and $\mathrm{NO}_{3}{ }^{-}-\mathrm{N}$ ), under $\mathrm{N}$ and $\mathrm{P}$ addition to identify the key factors affecting AMF abundance, diversity, and community composition.

\section{Materials and methods}

\section{Experimental description}

The field experiment was conducted at the Huanjiang Observation and Research Station for Karst Ecosystems $\left(107^{\circ} 51^{\prime}-108^{\circ} 43^{\prime} \mathrm{E}, 24^{\circ} 44^{\prime}-25^{\circ} 33^{\prime} \mathrm{N}\right)$, Chinese Academy of Sciences, Guangxi Province, southwest China. The region has a subtropical monsoon climate, and the average annual temperature and precipitation are $18.5^{\circ} \mathrm{C}$ and $1380 \mathrm{~mm}$, respectively. The wet season occurred from April to September and the dry season, from October to March. The average monthly temperatures in December 2016 and July 2017 were $9.9^{\circ} \mathrm{C}$ and $25.0^{\circ} \mathrm{C}$, respectively. The average monthly precipitation values in December 2016 and July 2017 were $16.8 \mathrm{~mm}$ and $359.4 \mathrm{~mm}$, respectively. The soil in this region was calcareous with high clay and $\mathrm{Ca}^{2+}$ content, which developed from a dolostone base. The study areas were characterized by a typical karst landscape with peak-cluster depression. Background $\mathrm{N}$ deposition in precipitation was about $37 \mathrm{~kg} \mathrm{~N} \mathrm{ha}^{-1}$ year $^{-1}$ (Zhu et al. 2015).

The fertilization experiment was set up with 12 plots $(5 \times$ $4 \mathrm{~m}$ ) in June 2014 and was conducted using a completely randomized block design with three replicates per treatment.
All plots were surrounded by concrete slabs to prevent soil, water, and nutrients from being transferred among plots. Each concrete slab was $0.15 \mathrm{~m}$ wide. About $0.5 \mathrm{~m}$ of each concrete slab was inserted into the soil, leaving $0.2 \mathrm{~m}$ protruding above the ground. The entire experimental site with 12 plots was surrounded by a 3-m-wide buffer strip, which was similar in all treatments. There were four treatments: control ( $\mathrm{CK}$, no fertilization), $\mathrm{N}$ addition ( $\mathrm{N}$, $100 \mathrm{~kg} \mathrm{~N} \mathrm{ha}^{-1}$ year $^{-1}$ ), $\mathrm{P}$ addition ( $\mathrm{P}, 50 \mathrm{~kg} \mathrm{P} \mathrm{ha}^{-1}$ year $^{-1}$ ), and combined $\mathrm{N}$ and $\mathrm{P}$ addition $\left(\mathrm{NP}, 100 \mathrm{~kg} \mathrm{~N}^{-1}\right.$ year $^{-1}+$ $50 \mathrm{~kg} \mathrm{P} \mathrm{ha}{ }^{-1}$ year $^{-1}$ ). The high $\mathrm{N}$ rate and medium $\mathrm{P}$ rate were used for two reasons. First, our previous studies had found that karst grasslands were $\mathrm{N}$-limited and that $\mathrm{N}$ deposition in this region has been increasing year by year. Thus, we intended to examine the effects of a high rate of $\mathrm{N}$ deposition (100 kg N ha ${ }^{-1}$ year $^{-1}$ ) on AMF. Second, N deficiency was greater than $\mathrm{P}$ deficiency in the karst grassland relative to the karst primary forest (Zhang et al. 2015). To simplify the experiment, and on the basis of the N/P ratio, a medium rate of $\mathrm{P}$ addition $\left(50 \mathrm{~kg} \mathrm{P} \mathrm{ha}^{-1}\right.$ year $^{-1}$ ) was used.

Since June 2015, $16.7 \mathrm{~g} \mathrm{~N}$ as $\mathrm{NH}_{4} \mathrm{NO}_{3}$ and $8.3 \mathrm{~g} \mathrm{P}$ as $\mathrm{CaH}_{2} \mathrm{PO}_{4} \cdot \mathrm{H}_{2} \mathrm{O}$ alone or combined were mixed with $1.5 \mathrm{~L}$ of water and manually added each month with a sprayer over the grassland in each fertilization plot. Control plots were sprayed with $1.5 \mathrm{~L}$ of water. $\mathrm{NH}_{4} \mathrm{NO}_{3}$ and $\mathrm{CaH}_{2} \mathrm{PO}_{4} \cdot \mathrm{H}_{2} \mathrm{O}$ were dissolved in a 2 -L sprayer. The solution was sprayed evenly on the plants at each plot, carefully ensuring the restriction of the movement of the solution across plots when spraying the sides. Additionally, the rainfall in this study area was very heavy, and there was a large amount of rainfall every month, so the nutrients applied in the treatment can be guaranteed to reach the soil, and a small part of the nutrient remains on the vegetation. The grassland areas were covered by naturally developed grass communities, with Microstegium vagans (31.7\%), Apluda mutica L. (26.9\%), and Imperata cylindrica $(10.2 \%)$ as the dominant species in the CK treatment; M. vagans $(66.1 \%)$ and A. mutica L. $(20.2 \%)$ as the dominant species in the $\mathrm{N}$ treatment; M. vagans (47.8\%) and I. cylindrica $(38.0 \%)$ as the dominant species in the $\mathrm{P}$ treatment; and $M$. vagans $(51.2 \%)$ and A. mutica L. $(26.2 \%)$ as the dominant species in the NP treatment.

\section{Sample collection and soil property measurements}

Field sampling was conducted in December 2016 and July 2017. In each plot, soil samples (0- to 10-cm depth) were randomly collected with soil corers (diameter $2.5 \mathrm{~cm}$ ) at five points according to the " $\mathrm{S}$ " type. The five soil samples from each plot were blended to obtain uniform composite soil after the removal of visible plant residue, roots, and stones. In the laboratory, portions of the fresh soil samples were used for exchangeable $\mathrm{NH}_{4}{ }^{+}-\mathrm{N}$ and $\mathrm{NO}_{3}{ }^{-}-\mathrm{N}$ analyses. Another portion 
of the soil samples was immediately flash-frozen, stored in liquid nitrogen, and preserved at $-80{ }^{\circ} \mathrm{C}$ in the laboratory for DNA extraction. The other samples were air-dried and sieved through a 2-mm mesh for physicochemical analysis. The main soil properties were $\mathrm{pH}, 7.31$; soil organic $\mathrm{C}$, $31.86 \mathrm{~g} \mathrm{~kg}^{-1}$; total soil $\mathrm{N}$ (TN), $2.06 \mathrm{~g} \mathrm{~kg}^{-1}$; total soil $\mathrm{P}$ (TP), $0.44 \mathrm{~g} \mathrm{~kg}^{-1}$; and $\mathrm{Ca}, 0.73 \mathrm{~g} \mathrm{~mL}^{-1}$; the aggregate sizes in the $>1 \mathrm{~mm}, 0.25-1-\mathrm{mm}$, and $<0.25-\mathrm{mm}$ fractions were $90.08,8.50$, and 1.42 , respectively.

Soil $\mathrm{pH}$ (1:2.5 soil/water ratio) was determined using a $\mathrm{pH}$ meter (Metter-Toledo 320). The exchangeable $\mathrm{NH}_{4}{ }^{+}-\mathrm{N}$ and $\mathrm{NO}_{3}{ }^{-}-\mathrm{N}$ contents were analyzed using $2 \mathrm{M} \mathrm{KCl}$ extraction (10 g soil, $80 \mathrm{~mL} \mathrm{KCl}^{-1}$ ) and were measured using an autoanalyzer (FIAstarTM 5000; FOSS, Pål Anders, Sweden) (Hood-nowotny et al. 2010). TN was determined with an Element Auto-Analyzer (Vario MAX CN; Elementar, Hanau, Germany). TP was determined by acid digestion with a solution of $\mathrm{H}_{2} \mathrm{SO}_{4}+\mathrm{HClO}_{4}$. Available $\mathrm{P}(\mathrm{AP})$ was analyzed by the molybdenum blue colorimetric method (Carter and Gregorich 2006; Chen et al. 2018a, b).

\section{Soil DNA extraction and real-time PCR}

Soil DNA was extracted from $0.3 \mathrm{~g}$ of each soil sample using the Fast DNA® SPIN Kit for Soil (MP Biomedicals, Santa Ana, CA, USA). Extraction was conducted according to the manufacturer's instructions. Extracted DNA was diluted approximately tenfold with nuclease-free water for real-time polymerase chain reaction (qPCR) amplification.

AMF abundance was determined using an ABI Prism 7900 system (Applied Biosystems, Foster City, CA, USA). DNA was used as a template to amplify a region within AMF 18S SSU rRNA using AMV4.5NF (AAGCTCGTAGTTGA ATTTCG) and AMDGR (CCCAACTATCCCTATTAATC AT) primers (Sato et al. 2005). The $10-\mu \mathrm{L}$ reaction volume contained $5 \mu \mathrm{L} 2 \times$ SYBR Premix Ex TaqTM, $0.2 \mu \mathrm{L}$ Rox (Takara Bio, Kusatsu, Japan), $0.3 \mu \mathrm{L}\left(0.4 \mu \mathrm{mol} \mathrm{L}{ }^{-1}\right)$ of both forward and reverse primers, $1 \mu \mathrm{L}\left(5 \mathrm{ng} \mu \mathrm{L}^{-1}\right)$ of sample template DNA, and $3.2 \mu \mathrm{L}$ of nuclease-free water. PCR runs started at $94{ }^{\circ} \mathrm{C}$ for $3 \mathrm{~min}$, followed by 30 cycles of $94{ }^{\circ} \mathrm{C}$ for $45 \mathrm{~s}, 60^{\circ} \mathrm{C}$ for $45 \mathrm{~s}$, and $72{ }^{\circ} \mathrm{C}$ for $1 \mathrm{~min}$. Standard curves used to quantify the AMF gene were created using a tenfold dilution series of plasmids containing the target gene. The $R^{2}$ values of the standard curve were $>0.993$, and amplification efficiencies were around $80 \%$.

\section{Illumina HiSeq sequencing and bioinformatic analyses}

PCR amplicons for HiSeq sequencing were conducted using nested PCR. AML1 (ATCAACTTTCGATGGTAGGA TAGA) and AML2 (GAACCCAAACACTTTGGTTTCC) primers were used to amplify an AMF 18S rRNA gene fragment (Lee et al. 2008). PCR was carried out using a $50-\mu \mathrm{L}$ reaction system with $2.5 \mu \mathrm{L}$ of template DNA, $25 \mu \mathrm{L}$ of $2 \times$ PCR Ex Taq (Takara Bio), $1.25 \mu \mathrm{L}$ of each primer (10 $\mu \mathrm{mol} \mathrm{L}^{-1}$ ), and deionized water to make up the volume. The PCR program consisted of $94{ }^{\circ} \mathrm{C}$ for $5 \mathrm{~min}$, followed by 35 cycles of $94{ }^{\circ} \mathrm{C}$ for $30 \mathrm{~s}, 58{ }^{\circ} \mathrm{C}$ for $45 \mathrm{~s}$, and $72{ }^{\circ} \mathrm{C}$ for $1 \mathrm{~min}$, followed by a final extension period of $10 \mathrm{~min}$ at $72^{\circ} \mathrm{C}$. The first PCR product was diluted 50 times. The dilutions were used as template DNA in a second PCR performed using the designed primers AMV4.5NF and AMDGR as follows: $94{ }^{\circ} \mathrm{C}$ for $3 \mathrm{~min}$, followed by 30 cycles of $94^{\circ} \mathrm{C}$ for $45 \mathrm{~s}, 60^{\circ} \mathrm{C}$ for $45 \mathrm{~s}$, and $72{ }^{\circ} \mathrm{C}$ for $1 \mathrm{~min}$, ending with a final extension at $72{ }^{\circ} \mathrm{C}$ for $10 \mathrm{~min}$. The barcode sequences $(6 \mathrm{bp})$ were linked to the $5^{\prime}$-end of the primers to distinguish the sequences of each sample. Fifty-microliter reaction mixtures contained $2.5 \mu \mathrm{L}$ of template DNA, $25 \mu \mathrm{L}$ of $2 \times$ PCR Ex Taq (Takara Bio), $1.25 \mu \mathrm{L}$ of each primer $\left(10 \mu \mathrm{mol} \mathrm{L}{ }^{-1}\right)$, and $20 \mu \mathrm{L}$ of water. There were two technical replicates for each sample, which was subsequently pooled into one tube. Negative controls were included to determine contaminant DNA originating from DNA extraction kits (Schöler et al. 2017; Vestergaard et al. 2017). PCR products were assessed using the Illumina HiSeq $\times$ Ten 250-bp paired-end sequencing platform at Novogene (Beijing, China) after purification using the GeneJET Gel Extraction Kit (Thermo Fisher Scientific, Vilnius, Lithuania).

AMF sequence data were processed following the UPARSE pipeline in USEARCH (v.10.0.240; Edgar 2010) and R (R Development Core Team 2018). Specifically, paired-end reads were spliced to produce contigs assigned to each sample based on their barcodes using QIIME. All contigs were merged using the "-fastq_mergepairs" USEARCH command, and primers were truncated with the "-fastx_truncate" USEARCH command. Reads were removed prior to analysis if they were shorter than $200 \mathrm{bp}$, contained any ambiguous bases, had an average quality score lower than 30, or had any nucleotide mismatches within the barcode or primer using the "-fastq_filter" USEARCH command. Then, AMF operational taxonomic unit (OTU)-representative sequences were picked out at $97 \%$ sequence similarity. OTU sequences were aligned to the SILVA SSU database. Sequences that failed to be aligned to the reference database were manually checked and verified with BLAST in NCBI, and sequences that did not belong to AMF were discarded. Subsequently, a phylogenetic tree was constructed in MEGA using the neighbor-joining algorithm. After dereplicating the sequences grouped together in the phylogenetic tree with similarities higher than $97 \%$, a new group of AMF OTU representatives was manually picked out, and the normalized OTU table was calculated in USEARCH. After the sequence number of each rarefied sample reached 10,000 , the $\alpha$ diversity was calculated in $\mathrm{R}$ using the "vegan" package. 


\section{Statistical analyses}

Repeated measures analysis of variance (ANOVA) was carried out with function "LSD.test" of R package "agricolae" (de Mendiburu 2014) to reveal the differences in AMF abundance, richness, and Chaol estimator values among different fertilization treatments or different sampling times in the same treatment $(p<0.05)$. Non-metric multidimensional scaling (NMDS) and permutational multivariate analysis of variance (PERMANOVA) were used to investigate the effect of seasonal changes and fertilization on AMF community compositions. NMDS and PERMANOVA were carried out in function "metaNMDS" and "adonis2" of R package "vegan" (Oksanen et al. 2017) using a distance matrix estimated following the methods of Bray-Curtis. Multivariate analysis of variance (MANOVA) was applied to determine the main and interactive effects of seasonal changes and fertilization on AMF abundance, richness, and Chao 1 values in $\mathrm{R}$ function "aov." The "linear discriminant analysis effect size" (LEfSe) method was used to determine the AMF community composition differences between December and July (Segata et al. 2011). The LEfSe was carried out with default parameters in the online Galaxy tool developed by Huttenhower's group (http://huttenhower.sph.harvard.edu/ galaxy/). A structural equation modeling (SEM) framework was applied to investigate the relationships among environmental factors, AMF abundance, and richness. SEM was carried out with the Amos 21.0 software package (Smallwaters Corporation, Chicago, IL, USA). The relationships between environmental factors and AMF abundance and richness were analyzed using Pearson correlation tests before the SEM procedure. The significance of environmental variables $(p<0.05)$ in the Pearson correlation was retained for the following SEM construction. We established the best relationship based on the model instructions. $p$ values, $\chi^{2}$, goodness-of-fit indices (GFIs), and root mean square errors of approximation (RMSEA) were used to evaluate the structural equation model fit ( $\mathrm{Hu}$ et al. 2014). The multivariate regression trees were performed with function "mvpart" of R package "mvpart" to determine the relationships between environmental factors and AMF community composition. All the other data and image preparation, if not specifically explained, were performed using R.

\section{Results}

\section{Soil AMF abundance, species richness, and Chao1 estimator values}

In total, there were 221 OTUs for all sequences after chimeras and singletons were discarded. Soil AMF abundance ranged from $7.20 \times 10^{7}$ to $1.92 \times 10^{8}$ copies $g^{-1}$ dry soil.
Table 1 Effects of seasonal changes, $\mathrm{N}$ addition, $\mathrm{P}$ addition, and their interaction on the richness, Chaol estimator values, abundance, and community composition of arbuscular mycorrhizal fungi

\begin{tabular}{lcccl}
\hline Items & Richness & Chao1 & Abundance & Community composition \\
\hline$s^{\mathrm{a}}$ & $17.912^{* * * *}$ & $16.118^{* *}$ & $20.422^{* * * *}$ & $3.432^{* *}$ \\
$n^{\mathrm{b}}$ & 0.076 & 0.032 & $14.352^{* *}$ & 1.573 \\
$p^{\mathrm{c}}$ & $7.533^{*}$ & $7.977^{*}$ & 0.890 & 1.357 \\
$s \times n^{\mathrm{d}}$ & 1.462 & 1.343 & $7.535^{*}$ & 1.213 \\
$s \times p^{\mathrm{e}}$ & 0.680 & 0.913 & 0.708 & 0.935 \\
$n \times p^{\mathrm{f}}$ & 0.027 & 0.221 & 0.051 & 0.718 \\
$s \times n \times p^{\mathrm{g}}$ & 1.740 & 1.842 & 0.134 & 0.816 \\
\hline
\end{tabular}

${ }^{\mathrm{a}}$ Effect of seasonal changes

${ }^{\mathrm{b}}$ Effect of $\mathrm{N}$ addition

${ }^{\mathrm{c}}$ Effect of $\mathrm{P}$ addition

${ }^{\mathrm{d}}$ Interaction effect of seasonal changes and $\mathrm{N}$ addition

${ }^{\mathrm{e}}$ Interaction effect of seasonal changes and $\mathrm{P}$ addition

${ }^{\mathrm{f}}$ Interaction effect of $\mathrm{N}$ and $\mathrm{P}$ addition

${ }^{\mathrm{g}}$ Interaction effect of seasonal changes and $\mathrm{N}$ and $\mathrm{P}$ addition

$* p<0.05, * * p<0.01, * * * p<0.001$

AMF abundance was significantly affected by seasonal changes, $\mathrm{N}$ addition, and interaction effects of seasonal changes and $\mathrm{N}$ addition, while AMF richness and Chao 1 values were significantly affected by seasonal changes and $\mathrm{P}$ addition (Table 1).

Specifically, AMF abundance in the N and NP treatments was significantly higher in July (summer) than in December (winter). Among the fertilization treatments, AMF abundance in the $\mathrm{P}$ treatment plots was significantly less than that in the N and NP treatment plots in July. The highest AMF abundance occurred in the $\mathrm{N}$-supplemented plots, and the lowest occurred in the P-supplemented plots (Fig. 1a). Conversely, soil AMF species richness and Chao1 values followed similar seasonal variations, which were higher in December than in July. AMF richness and Chaol estimator values of the $\mathrm{P}$ treatment were significantly higher than those of the control in July. There was no significant difference in AMF abundance, species richness, or Chao 1 values for any of the treatments in December (Fig. 1b, c).

\section{Soil AMF community composition}

AMF communities at order, family, and genus level are detailed in Fig. 2. AMF communities belonged to Paraglomerales, Glomerales, and Diversisporales. The most abundant order was Glomerales, and its abundance was higher in December (95.38\%) than in July (91.07\%) (Fig. 2a). As shown in Fig. 2b, AMF communities could be grouped into six main families, and the most abundant family was Glomeraceae. AMF communities could be 

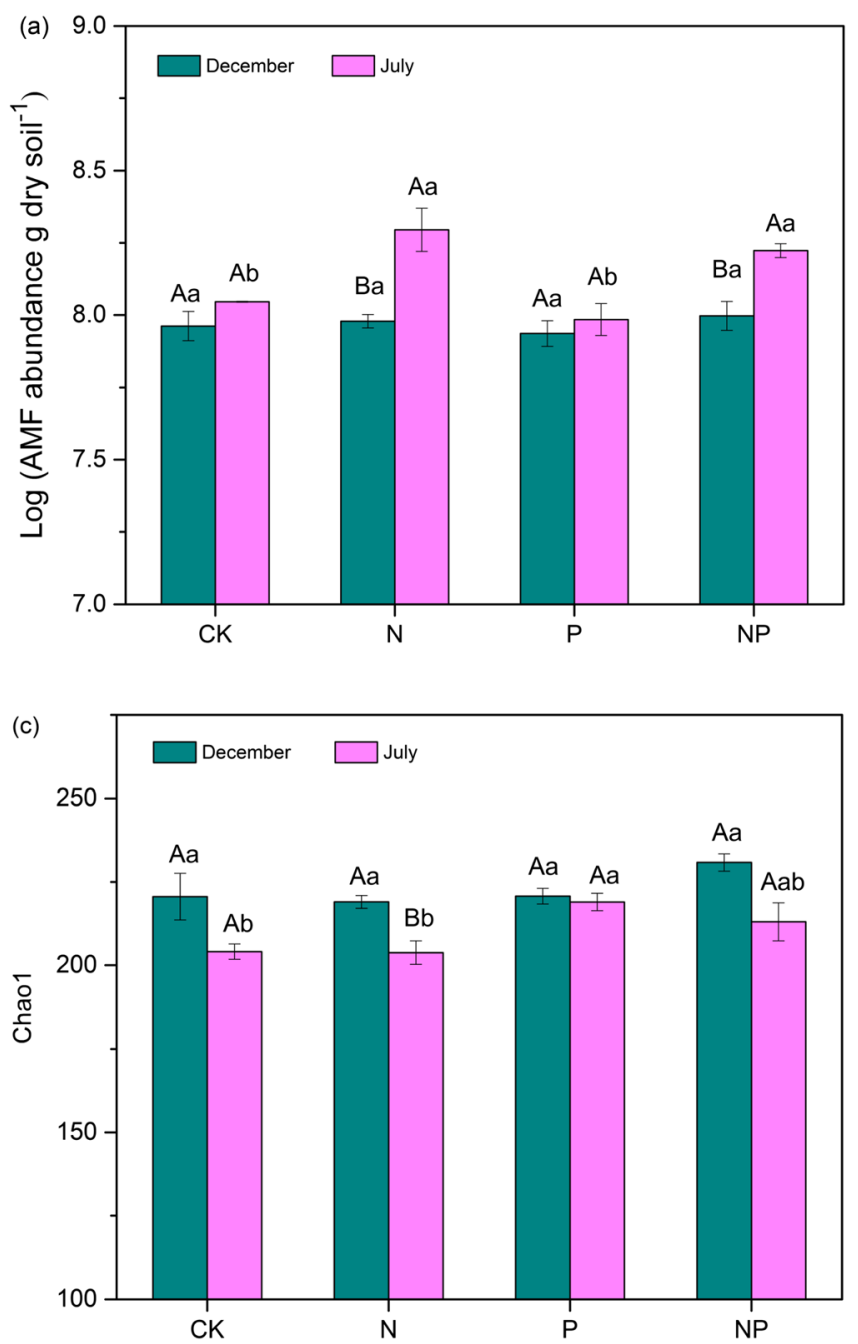

Fig. 1 Effect of N, P, and NP treatments on arbuscular mycorrhizal fungi properties in December 2016 and July 2017. a Soil arbuscular mycorrhizal fungi abundance, $\mathbf{b}$ richness, and $\mathbf{c}$ Chaol values. CK, $\mathrm{N}$, $\mathrm{P}$, and NP indicate no fertilization, the addition of $100 \mathrm{~kg} \mathrm{~N} \mathrm{ha}^{-1} \mathrm{year}^{-1}$, the addition of $50 \mathrm{~kg} \mathrm{P} \mathrm{ha}^{-1} \mathrm{year}^{-1}$, and combined $\mathrm{N}$ and $\mathrm{P}$ addition of

further identified as belonging to 10 main genera, including Septoglomus, Scutellospora, Sclerocystis, Rhizophagus, Paraglomus, Glomus, Funneliformis, Diversispora, Claroideoglomus, and Acaulospora (Fig. 2c).

AMF community composition was significantly affected by seasonal changes, but $\mathrm{N}$ and $\mathrm{P}$ addition had no significant effect on it (Table 1). NMDS showed that community composition differed between December and July (Fig. 3). Regardless of treatment, the numbers of the genera Scutellospora, Redeckera, and Diversispora were higher in July, whereas Sclerocystis and Funneliformis were more abundant in December (Fig. 4a). Scutellospora, Redeckera, and Diversispora belong to Diversisporales. Both Sclerocystis and Funneliformis belong to Glomerales (Fig. 4b).

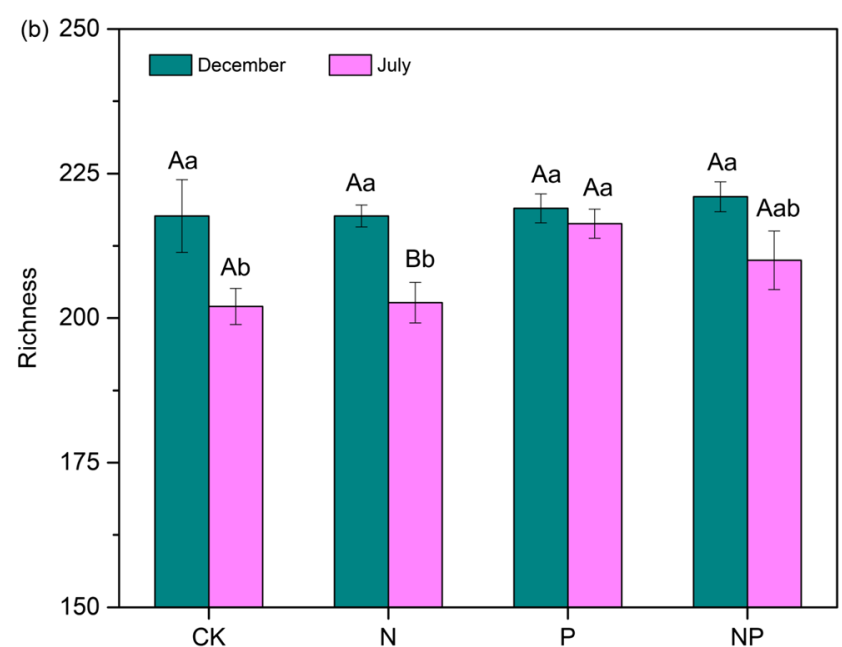

$100 \mathrm{~kg} \mathrm{~N} \mathrm{ha}^{-1}$ year $^{-1}$ plus $50 \mathrm{~kg} \mathrm{P}^{-1}$ year $^{-1}$, respectively. Different lowercase letters indicate significant differences between treatments at the same sampling time $(p<0.05)$; different uppercase letters indicate significant differences at different sampling time for the same treatment $(p<0.05)$. Bars show standard error of the mean $(n=3)$

\section{Driving factors for AMF diversity and community composition}

SEM analysis generated a model that fit the causal hypothesis well $\left(x^{2}=4.38, \mathrm{df}=6, \mathrm{GFI}=0.95\right.$, RMSEA $<$ 0.001 ) and explained $41 \%$ and $56 \%$ of the variance in AMF abundance and richness, respectively. According to the path coefficients $(\lambda)$ for the casual models, TN showed the largest positive and negative effect on AMF abundance and richness, respectively. AMF richness was significantly correlated with $\mathrm{AP}$ and $\mathrm{pH}$, while AP was significantly correlated with TP and $\mathrm{pH}$. Moreover, TP was significantly correlated with TN (Fig. 5). According to the multivariate regression tree analysis, $\mathrm{pH}$ and $\mathrm{NO}_{3}^{-}$$\mathrm{N}$ were the main factors affecting AMF community composition (Fig. 6). 
(a)

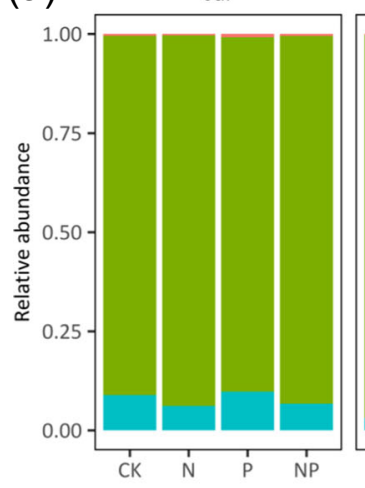

Dec

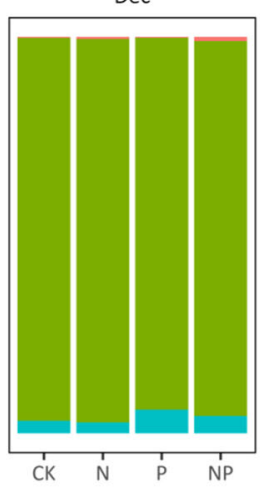

(c)

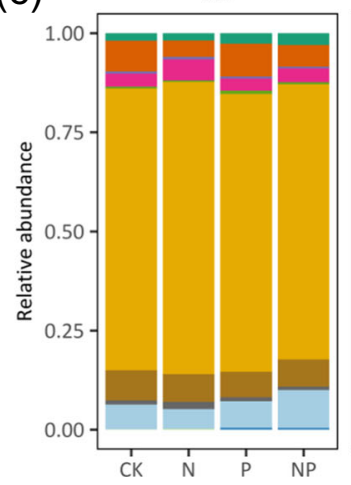

Order

Paraglomerales Glomerales

Diversisporales

Other (b)

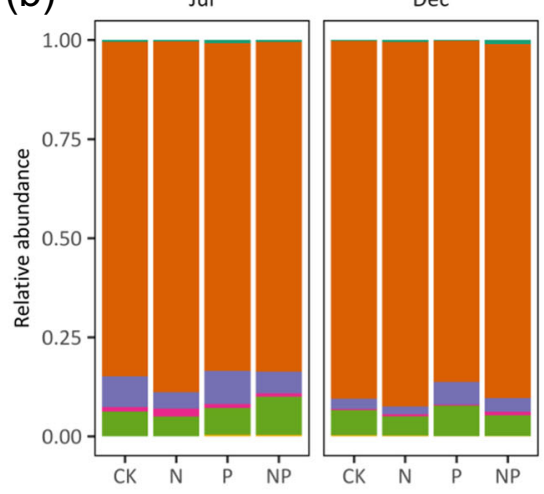

Family

Paraglomeraceae

Glomeraceae

Gigasporaceae

Diversisporaceae

Claroideoglomeraceae

Acaulosporaceae

Other

Fig. 2 Soil arbuscular mycorrhizal fungi community compositions at a order, $\mathbf{b}$ family, and $\mathbf{c}$ genus level under different treatments in December 2016 and July 2017; CK, N, P, and NP represent no fertilization, N addition of $100 \mathrm{~kg} \mathrm{~N} \mathrm{ha}^{-1}$ year $^{-1}, \mathrm{P}$ addition of $50 \mathrm{~kg} \mathrm{P}^{-1}$ year ${ }^{-1}$,

and combined $\mathrm{N}$ and $\mathrm{P}$ addition of $100 \mathrm{~kg} \mathrm{~N}^{-1}$ year $^{-1}$ plus $50 \mathrm{~kg} \mathrm{P}$ $\mathrm{ha}^{-1}$ year $^{-1}$, respectively. Other: the sum of order, family, and genus occupying $<0.5 \%$ of the total population
Fig. 3 Non-metric

multidimensional scaling

(NMDS) ordinations of

arbuscular mycorrhizal fungi

community composition based on

OTUs in 24 soil samples under

four treatment regimes in

December 2016 and July 2017.

$\mathrm{CK}$, no fertilization; $\mathrm{N}$,

$100 \mathrm{~kg} \mathrm{~N} \mathrm{ha}^{-1}$ year $^{-1}$; P, $50 \mathrm{~kg} \mathrm{P}$

$\mathrm{ha}^{-1}$ year $^{-1}$; NP,

$100 \mathrm{~kg} \mathrm{~N} \mathrm{ha}^{-1}$ year $^{-1}$ plus $50 \mathrm{~kg} \mathrm{P}$ ha $^{-1}$ year $^{-1}$

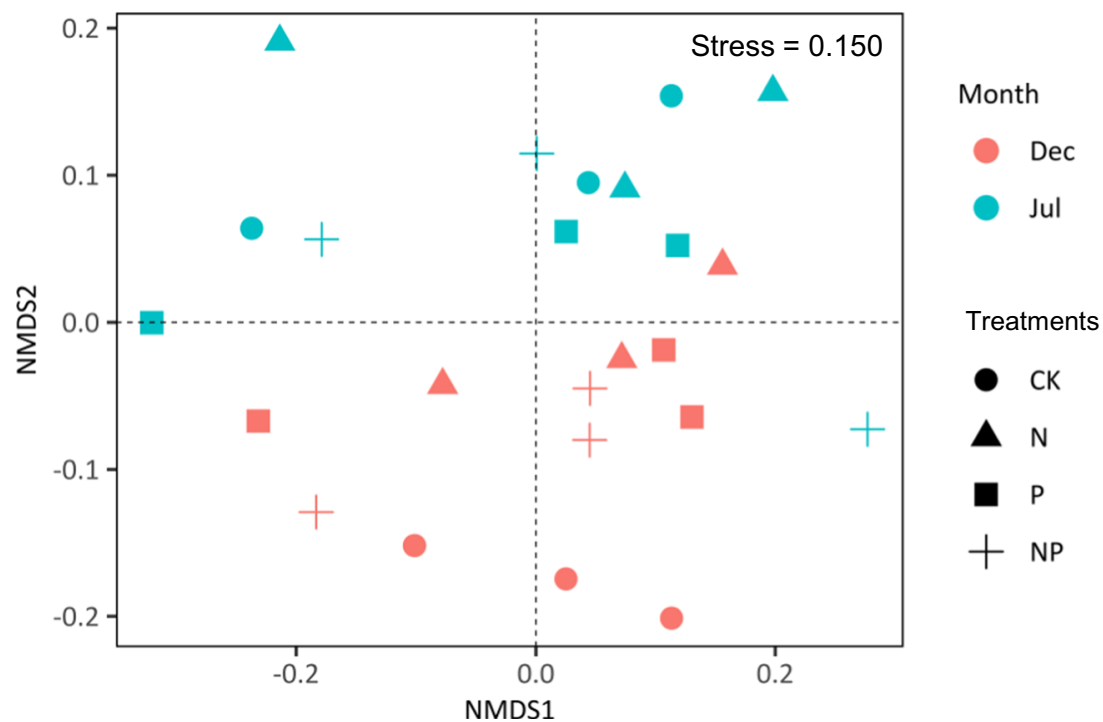




\section{(a) $\square$ Dec $\square$ Jul}

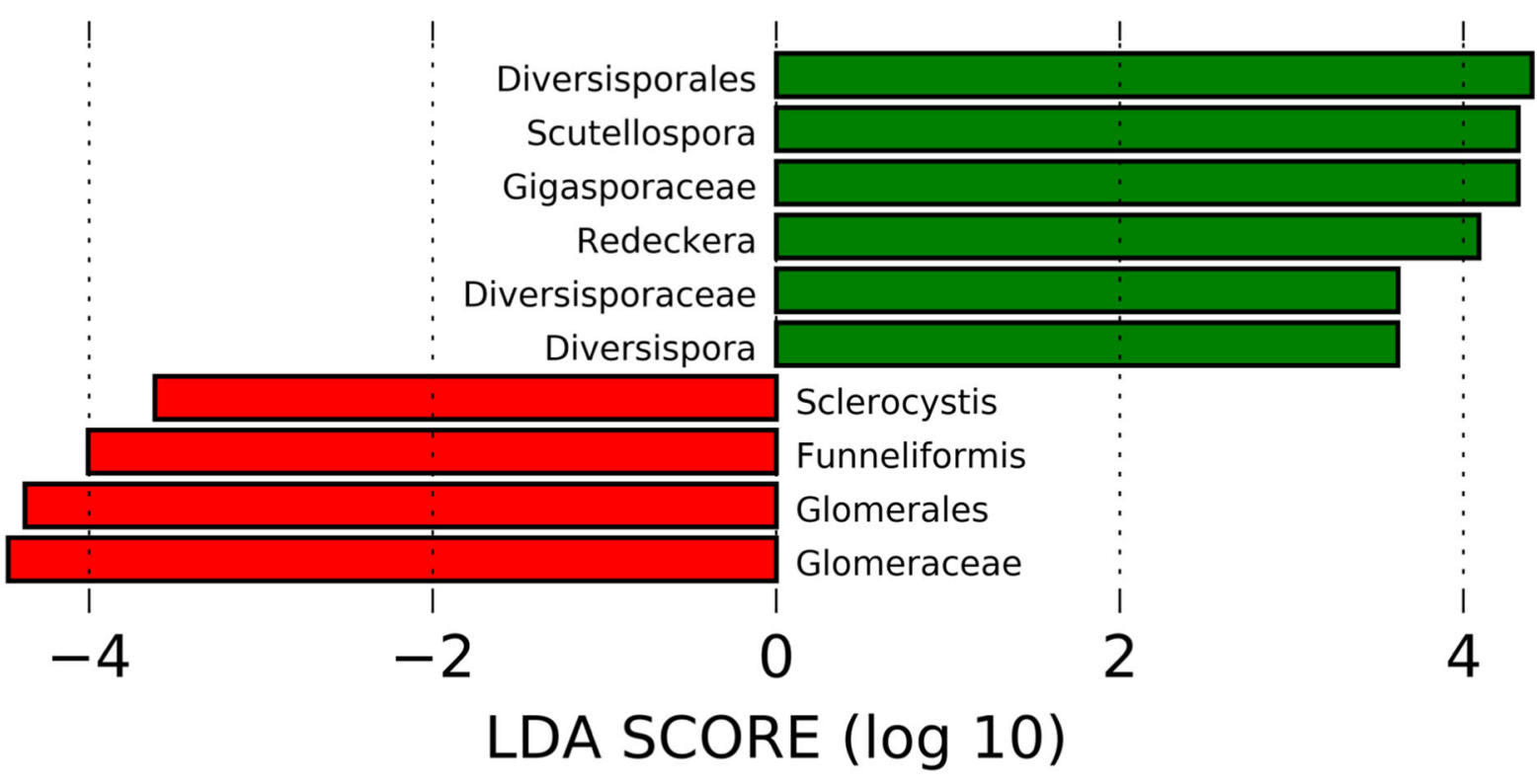

(b)

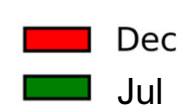

Jul

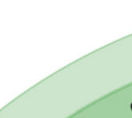

e
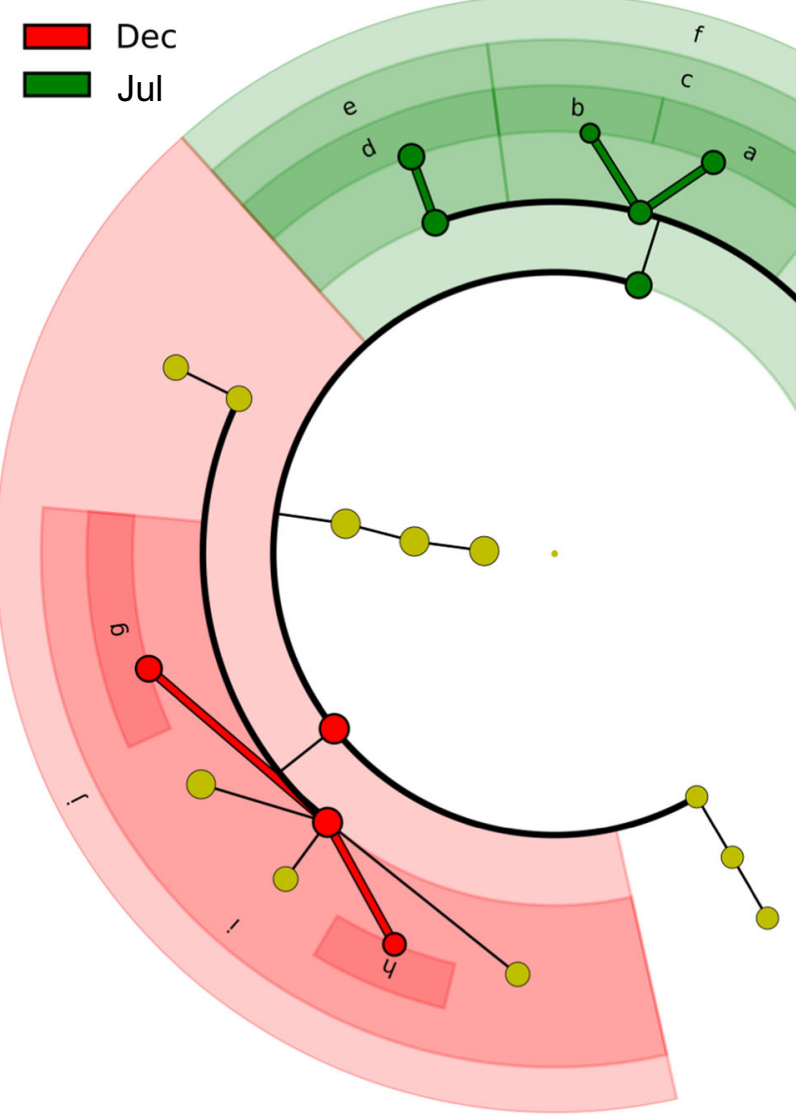

Fig. 4 Amplicon sequencing results using the "linear discriminant analysis effect size" (LEfSe) analysis between December and July. a Responses of the proportions of putative functions determined using LEfSe analysis and $\mathbf{b}$ differences in soil arbuscular mycorrhizal fungi community composition. The figure illustrates the LDA score of

arbuscular mycorrhizal fungi features. Only significant features with an LDA score larger than 2.0 were obtained. The arbuscular mycorrhizal fungi lineages (in green) were significantly more abundant in July, while the arbuscular mycorrhizal fungi lineages (in red) were significantly more abundant in December 


\section{Discussion}

\section{Seasonal variation in AMF abundance, richness, Chao1 values, and community composition}

There was no significant change in AMF abundance in December (Fig. 1a). This could have been caused by a shift in plant phenology, including plant-derived labile nutrients, litter, and root exudates (Wang et al. 2018; Zubek et al. 2016). Typically, plants produced new roots and stimulated an increased AMF mycelial network that extended into the soil for nutrient uptake during the growing season (Bohrer et al. 2004; Johnson et al. 2010). In the present study, rains and available nutrients $\left(\mathrm{NH}_{4}{ }^{+}-\mathrm{N}\right.$ and $\left.\mathrm{NO}_{3}{ }^{-}-\mathrm{N}\right)$ were lower in winter than in summer (Fig. S1b, c). Yang et al. (2010) showed that soil water availability could explain the change in AMF biomass by affecting dissolved nutrients in the soil. Plants grow slowly over the winter and demand fewer nutrients compared to the growing season; therefore, we predicted that AMF colonization would be low in December. Meanwhile, some microorganisms may have been dormant or non-viable due to low soil temperature and moisture during winter. Moreover, soil fungivores prefer consuming plant roots over fungal hyphae in the growing season, and their feces are used by AMF for extracting nutrients; both of these factors increase AMF abundance. Conversely, less plant roots are available for fungivores in the winter, leading to the consumption of fungal hyphae and in turn, decreased AMF abundance (Ngosong et al. 2014; Thomsen and Hart 2018).
Seasonal changes significantly affected AMF abundance, richness, Chao 1 values, and community composition (Table 1). The AMF richness and Chaol values showed the opposite results compared to AMF abundance (Fig. 1). This was similar to the findings of Dumbrell et al. (2011), wherein AMF species composition and $\alpha$ diversity levels differed between cooler (winter) and warmer (summer) periods. Other studies have shown that AMF diversity was sensitive to soil temperature (Gavito et al. 2003). Thus, the lower temperature might have restricted microenvironmental changes during the winter, which stimulated AMF community compositional changes and increased the spatial turnover of species (Dumbrell et al. 2011). In the present study, the numbers of the genera Sclerocystis and Funneliformis were significantly higher in December than in July (Fig. 4), suggesting that Sclerocystis and Funneliformis grow and outcompete other rare taxa during the winter. In addition, it is actually the decreased photosynthesis that limits $\mathrm{C}$ availability during winter, while the $\mathrm{C}$ supply increases within the growing season (Dumbrell et al. 2010). Consequently, the higher AMF species richness in December probably reflects a more competitive scenario in terms of the capture of limited resources (Tilman 1987).

\section{Effects of $\mathbf{N}$ and $\mathbf{P}$ addition on AMF abundance, richness, Chao1 values, and community composition}

The effects of $\mathrm{N}$ and $\mathrm{P}$ application or deposition on AMF abundance and community composition have been demonstrated (Bi et al. 2003; Liu et al. 2013; Treseder and Allen

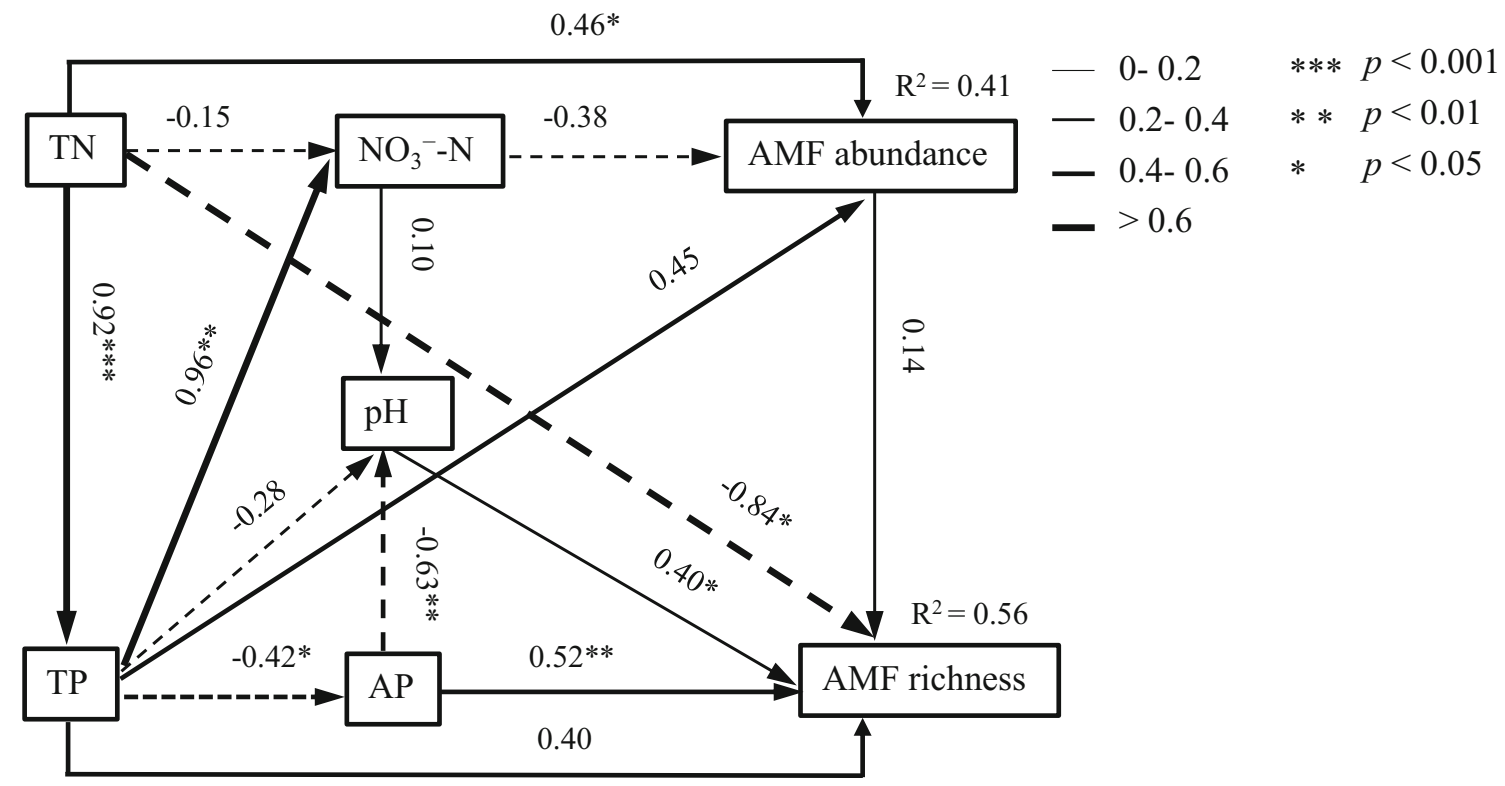

Fig. 5 Structural equation model (SEM) showing the direct and indirect effects of TN, TP, $\mathrm{NO}_{3}{ }^{-} \mathrm{N}, \mathrm{AP}$, and $\mathrm{pH}$ on arbuscular mycorrhizal fungi abundance and richness. TN, total $\mathrm{N} ; \mathrm{NO}_{3}{ }^{-} \mathrm{N}$, nitrate $\mathrm{N}$; TP, total P; AP, available $\mathrm{P}$. The width of the arrows indicates the strength of the standardized path coefficient. The solid lines indicate positive path coefficients; dashed lines, negative path coefficients; and $R^{2}$ values, the proportion of variance explained for each endogenous variable $(n=24)$ 
Fig. 6 The relationships between environmental factors and arbuscular mycorrhizal fungi community composition. The relationships were determined using multivariate regression tree analysis at the OTU level. $\mathrm{NO}_{3}^{-}$ $\mathrm{N}$, nitrate $\mathrm{N}$. The bar plots and the numbers show the average relative abundances of OTUs in each split group and the sample number within each group, respectively

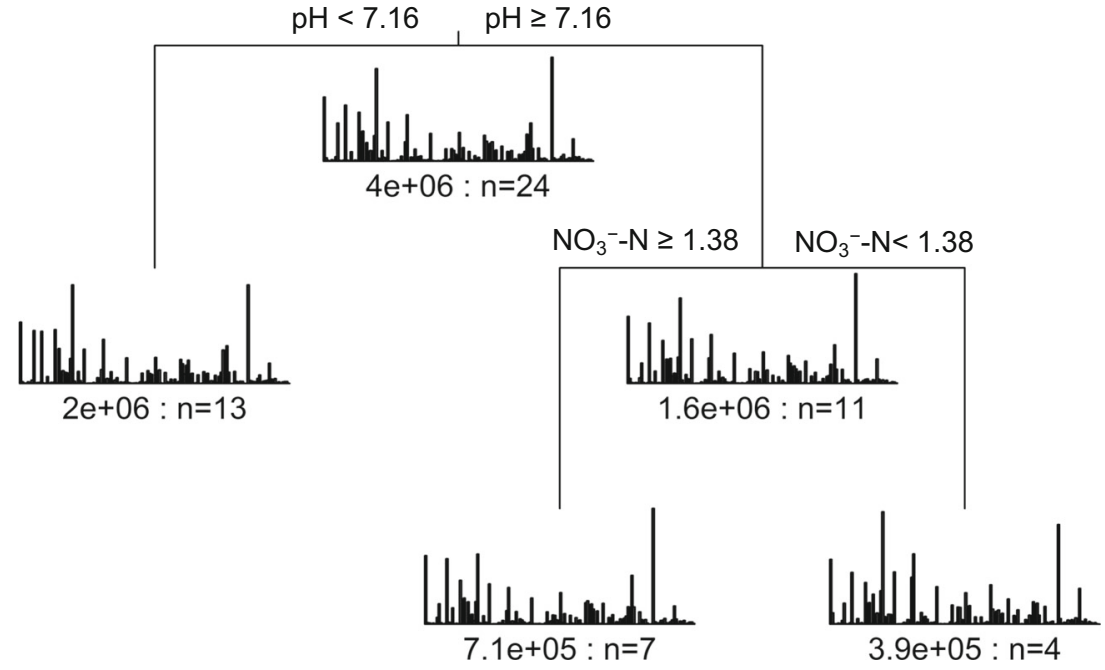

2002). However, AMF properties in different soils, climates, and plant communities have been found to differ (Jumpponen et al. 2005). We found that AMF abundance dramatically increased with the application of N and NP in July compared to the control, and it was similar between the treatment of $\mathrm{P}$ and the control (Fig. 1a). A meta-analysis reported that the effects of $\mathrm{N}$ input on AMF abundance differ between N-rich and $\mathrm{N}$ limited ecosystems (Treseder 2004). The AMF abundance generally declined with $\mathrm{N}$ enrichment. However, karst grassland is N-limited due to severe deforestation and agricultural expansion by human activities. When alleviating $\mathrm{N}$ limitation by high $\mathrm{N}$ input, a higher plant photosynthetic rate would result in increased AMF C allocation in exchange for nutrients (Delavaux et al. 2017; Treseder 2004). Furthermore, high N input could be insufficient to balance the N:P ratio and result in soil deficiency of $\mathrm{P}$. In this case, plant dependence on AMF for additional $P$ would increase (Delavaux et al. 2017). These results suggested that high $\mathrm{N}$ input resulted in $\mathrm{P}$ deficiency and more AMF investment to acquire limiting P. A previous study suggested that soil available $\mathrm{P}$ promotes AMF colonization at lower concentrations but inhibits colonization at higher concentrations (Xie et al. 2014). This suggests that $P$ levels limit plant growth in karst grasslands and that $\mathrm{P}$ input might stimulate AMF species richness to improve $\mathrm{P}$ acquisition. In our study, $\mathrm{N}$ application had a significant effect on AMF abundance, but $\mathrm{P}$ application had a significant effect on AMF richness and Chaol values (Table 1). These findings suggested that AMF abundance was sensitive to $\mathrm{N}$ addition, while AMF richness and Chaol values were sensitive to $\mathrm{P}$ addition after 2 years of $\mathrm{N}$ and $\mathrm{P}$ addition.

$\mathrm{N}$ addition, $\mathrm{P}$ addition, and their interaction yielded no significant effect on AMF community composition (Table 1). In contrast, Bhadalung et al. (2005) found that three unidentified species of Glomus were highly sensitive to NP fertilization, while other AMF species were slightly sensitive to the fertilization in 27-year long-term NP fertilization plots.
We found soil AMF communities to be dominated by Glomus (72.88\%) genera (Fig. 2c). Chen et al. (2018a, b) reported that in the restoration of disturbed habitats in Hong Kong, Glomus (10-24\%) was the most abundant genus, although significant proportions (51-83\%) of AMF could not be identified to the genus level due to limitations in the reference database. Meanwhile, analysis of the Tibetan alpine steppe rhizosphere found the most dominant genera to be Glomus, Diversispora, and Claroideoglomus, representing approximately $34.5 \%$, $33.3 \%$, and $21.8 \%$ of the total clones, respectively (Zhang et al. 2016). These results suggested that the dominant AMF species differed between the karst region and other regions and that Glomus spp. in karst regions have an increased ability to colonize adverse environments with low nutrients and high $\mathrm{Ca}^{2+}$ compared to other regions. Thus, grassland $\mathrm{N}$ and $\mathrm{P}$ application under different climate conditions and soil properties exert different influences on AMF composition (Gai et al. 2006; Johnson et al. 2003; Oehl et al. 2017).

\section{Key factors driving AMF abundance, richness, and community composition changes}

AMF abundance, diversity, and community composition may change with nutrient addition as a result of alterations in soil properties (Zheng et al. 2014). Based on SEM, TN was found to be the main positive predictor of AMF abundance but was the main negative factor of AMF richness (Table 2). Hence, increased TN levels under $\mathrm{N}$ addition might increase $\mathrm{AMF}$ abundance but decrease AMF richness (Delavaux et al. 2017; Johnson et al. 2003; Zheng et al. 2014). TN was significantly correlated with TP, which then directly affected AMF abundance and richness (Fig. 5). Because $\mathrm{N}$ and $\mathrm{P}$ nutrition are closely coupled, evidence suggested that the balance between $\mathrm{N}$ and $\mathrm{P}$ was a more important factor in governing fungal colonization than the effect of $\mathrm{N}$ or $\mathrm{P}$ alone (Miller et al. 2002; Sylvia and Neal 1990). 
Table 2 Direct, indirect, and total effects of environmental factors on arbuscular mycorrhizal fungi abundance and richness using a structural equation model (SEM)

Observed outcomes $(\lambda)$

\begin{tabular}{llllll}
\hline & $\mathrm{TN}^{\mathrm{a}}$ & $\mathrm{NO}_{3}{ }^{-}-\mathrm{N}^{\mathrm{b}}$ & $\mathrm{TPc}$ & $\mathrm{APd}$ & $\mathrm{pH}$ \\
\hline Direct & 0.46 & -0.38 & 0.45 & 0 & 0 \\
Indirect & 0.15 & 0 & -0.36 & 0 & 0 \\
Total & 0.61 & -0.38 & 0.09 & 0 & 0 \\
Direct & -0.84 & 0 & 0.40 & 0.52 & 0.40 \\
Indirect & 0.22 & 0.09 & -0.25 & -0.25 & 0 \\
Total & -0.62 & -0.09 & 0.15 & 0.27 & 0.40 \\
\hline
\end{tabular}

${ }^{\mathrm{a}}$ Total N

${ }^{\mathrm{b}}$ Nitrate $\mathrm{N}$

${ }^{\mathrm{c}}$ Total P

${ }^{\mathrm{d}}$ Available P

AMF community composition was significantly affected by $\mathrm{pH}$ and $\mathrm{NO}_{3}{ }^{-} \mathrm{N}$ (Fig. 6). Similarly, Zheng et al. (2014) observed that AMF community composition was mainly affected by available $\mathrm{P}, \mathrm{pH}$, and $\mathrm{NO}_{3}{ }^{-}-\mathrm{N}$ content in the QinghaiTibetan Plateau alpine meadow ecosystem, whereas EgertonWarburton et al. (2007) found that soil N, N:P, and host plant were the key drivers of AMF community composition by a cross-site test in five grasslands. $\mathrm{pH}$ has been reported as an important factor in regulating AMF diversity (Aliasgharzad et al. 2010; Zheng et al. 2014). In the present study, AMF richness was significantly correlated with $\mathrm{pH}$ (Fig. 5). It has also been reported that fertilization induces soil acidification on a global scale (Tian and Niu 2015). Changes in $\mathrm{pH}$ may regulate $P$ availability (Brady and Weil 2008). AP was significantly higher in the treatments of P and NP than in the control in July (Fig. S1), and AP was significantly correlated with soil $\mathrm{pH}$ (Fig. 5). These findings supported our hypothesis that $\mathrm{N}$ and $\mathrm{P}$ addition would induce a shift in AMF richness via a change in soil nutrient availability and $\mathrm{pH}$ levels. However, AMF abundance and richness were less susceptible to varied soil $\mathrm{pH}$ than to TN and AP (Table 2). These results indicated that soil nutrient availability had a greater effect on AMF abundance and diversity than $\mathrm{pH}$.

Sampling time significantly affected AMF abundance, richness, and Chaol values, as well as community composition. Temperature and precipitation were higher in July than in December in the study region. Warming and precipitation have been found to significantly affect plant phenology and nutrient availability (Brundrett 1991; da Silva et al. 2014; Sun et al. 2013). $\mathrm{N}$ addition could increase exchangeable $\mathrm{NH}_{4}{ }^{+}-\mathrm{N}$ and $\mathrm{NO}_{3}{ }^{-}-\mathrm{N}$ especially in July, which increased the AMF abundance in our study (Fig. S1b, c). This supports findings by Sun et al. (2017), according to which nutrient sources, temperature, and water regimes interactively affect labile organic matter. Consequently, $\mathrm{N}$ and $\mathrm{P}$ application at different times may have affected the availability and quantity of dissolved nutrients, and thus, may have indirectly driven the distribution of soil AMF abundance and richness.

\section{Conclusions}

This study showed that sampling time had a significant effect on AMF abundance, diversity, and community composition. Higher AMF abundance was found in July (summer) whereas higher AMF diversity was found in December (winter). Diversisporales was significantly richer in July while Glomerales was more abundant in December. Additionally, AMF abundance was significantly affected by the $\mathrm{N}$ addition while AMF diversity was significantly affected by the $\mathrm{P}$ addition. The $\mathrm{N}$ and $\mathrm{P}$ addition showed no significant effect on AMF community composition. AMF abundance closely linked to TN, but AMF richness was also significantly affected by AP and $\mathrm{pH}$. These findings suggested that the 2-year $\mathrm{N}$ and $\mathrm{P}$ application affected soil nutrient availability and induced a change in soil $\mathrm{pH}$, which directly affected AMF richness. Proper $\mathrm{P}$ addition is important to maintain the balance of the system with the increasing of $\mathrm{N}$ deposition. Future studies should focus on the variation in AMF abundance with high $\mathrm{N}$ deposition, and on AMF diversity when P became more limiting with high $\mathrm{N}$ deposition in post-agricultural succession in the early-stage karst region grasslands, ensuring that seasonal and nutrient availability variation are taken into account.

Funding information This study was supported by the National Key Research and Development Program (2016YFC0502400); the National Natural Science Foundation of China (31670529, 31870502, 31870503); the Youth Innovation Team Project of ISA, Chinese Academy of Sciences (2017QNCXTD ZJ); the Open Foundation of Key Laboratory of Agroecological Processes in Subtropical Region, Institute of Subtropical Agriculture, Chinese Academy of Sciences (NO. ISA2016302); and the Youth Innovation Promotion Association, Chinese Academy of Sciences Program (2015303).

\section{References}

Aliasgharzad N, Martensson L-M, Olsson PA (2010) Acidification of a sandy grassland favours bacteria and disfavours fungal saprotrophs as estimated by fatty acid profiling. Soil Biol Biochem 42:1058-1064

Bhadalung NN, Suwanarit A, Dell B, Nopamornbodi O, Thamchaipenet A, Rungchuang J (2005) Effects of long-term NP-fertilization on abundance and diversity of arbuscular mycorrhizal fungi under a maize cropping system. Plant Soil 270:371-382

Bi YL, Li XL, Christie P (2003) Influence of early stages of arbuscular mycorrhiza on uptake of zinc and phosphorus by red clover from a low-phosphorus soil amended with zinc and phosphorus. Chemosphere 50:831-837

Bohrer KE, Friese CF, Amon JP (2004) Seasonal dynamics of arbuscular mycorrhizal fungi in differing wetland habitats. Mycorrhiza 14:329-337

Brady NC, Weil RR (2008) The nature and properties of soils, 14th edn, Ch. 12. Prentice Hall 
Brundrett M (1991) Mycorrhizas in natural ecosystems. Adv Ecol Res 21: $171-313$

Camenzind T, Hempel S, Homeier J, Horn S, Velescu A, Wilcke W, Rillig MC (2014) Nitrogen and phosphorus additions impact arbuscular mycorrhizal abundance and molecular diversity in a tropical montane forest. Glob Chang Biol 20:3646-3659

Camenzind T, Homeier J, Dietrich K, Hempel S, Hertel D, Krohn A, Leuschner C, Oelmann Y, Olsson PA, Suárez JP, Rillig MC (2016) Opposing effects of nitrogen versus phosphorus additions on mycorrhizal fungal abundance along an elevational gradient in tropical montane forests. Soil Biol Biochem 94:37-47

Carter MR, Gregorich EG (2006) Soil sampling and methods of analysis, 2nd edn. Taylor and Francis Group, Boca Raton

Chen H, Li D, Xiao K, Wang K, Treseder K (2018a) Soil microbial processes and resource limitation in karst and non-karst forests. Funct Ecol 32:1400-1409

Chen XW, Wong JTF, Chen ZT, Leung AOW, Ng CWW, Wong MH (2018b) Arbuscular mycorrhizal fungal community in the topsoil of a subtropical landfill restored after 18 years. J Environ Manag 225:17-24

Cozzolino V, Pigna M, Di Meo V, Caporale AG, Violante A (2010) Effects of arbuscular mycorrhizal inoculation and phosphorus supply on the growth of Lactuca sativa L. and arsenic and phosphorus availability in an arsenic polluted soil under non-sterile conditions. Appl Soil Ecol 45:262-268

da Silva IR, de Mello CMA, Ferreira Neto RA, da Silva DKA, de Melo AL, Oehl F, Maia LC (2014) Diversity of arbuscular mycorrhizal fungi along an environmental gradient in the Brazilian semiarid. Appl Soil Ecol 84:166-175

de Mendiburu F (2014) Agricolae: statistical procedures for agricultural research. R package version 1.2-0. http://CRAN.R-project.org/ package $=$ agricolae

Delavaux CS, Camenzind T, Homeier J, Jimenez-Paz R, Ashton M, Queenborough SA (2017) Nutrient enrichment effects on mycorrhizal fungi in an Andean tropical montane forest. Mycorrhiza 27:311-319

Dumbrell AJ, Nelson M, Helgason T, Dytham C, Fitter AH (2010) Idiosyncrasy and overdominance in the structure of natural communities of arbuscular mycorrhizal fungi: is there a role for stochastic processes? J Ecol 98:419-428

Dumbrell AJ, Ashton PD, Aziz N, Feng G, Nelson M, Dytham C, Fitter AH, Helgason T (2011) Distinct seasonal assemblages of arbuscular mycorrhizal fungi revealed by massively parallel pyrosequencing. New Phytol 190:794-804

Edgar RC (2010) Search and clustering orders of magnitude faster than BLAST. Bioinformatics 26:2460-2461

Egerton-Warburton LM, Johnson NC, Allen EB (2007) Mycorrhizal community dynamics following nitrogen fertilization: a cross-site test in five grasslands. Ecol Monogr 77:527-544

Gai JP, Feng G, Cai XB, Christie P, Li XL (2006) A preliminary survey of the arbuscular mycorrhizal status of grassland plants in southern Tibet. Mycorrhiza 16:191-196

Galloway JN, Dentener FJ, Capone DG, Boyer EW, Howarth RW, Seitzinger SP, Asner GP, Cleveland CC, Green PA, Holland EA, Karl DM, Michaels AF, Porter JH, Townsend AR, Vorosmarty CJ (2004) Nitrogen cycles: past, present, and future. Biogeochemistry 70:153-226

Gavito ME, Schweiger P, Jakobsen I (2003) P uptake by arbuscular mycorrhizal hyphae: effect of soil temperature and atmospheric $\mathrm{CO}_{2}$ enrichment. Glob Chang Biol 9:106-116

He D, Xiang X, He JS, Wang C, Cao G, Adams J, Chu H (2016) Composition of the soil fungal community is more sensitive to phosphorus than nitrogen addition in the alpine meadow on the QinghaiTibetan Plateau. Biol Fertil Soils 52:1059-1072

Hofmeister J, Mihaljevic M, Hosek J, Sadlo J (2002) Eutrophication of deciduous forests in the Bohemian Karst (Czech Republic): the role of nitrogen and phosphorus. For Ecol Manag 169:213-230
Hood-nowotny R, Umana NHN, Inselbacher E, Lachouani PO, Wanek W (2010) Alternative methods for measuring inorganic, organic, and total dissolved nitrogen in soil. Soil Sci Soc Am J 74(3):1018-1027

Hu YJ, Xiang D, Veresoglou SD, Chen FY, Chen YL, Hao ZP, Zhang X, Chen BD (2014) Soil organic carbon and soil structure are driving microbial abundance and community composition across the arid and semi-arid grasslands in northern China. Soil Biol Biochem 77:51-57

Huang Z, Liu B, Davis M, Sardans J, Penuelas J, Billings S (2016) Longterm nitrogen deposition linked to reduced water use efficiency in forests with low phosphorus availability. New Phytol 210:431-442

Jiang Z, Lian Y, Qin X (2014) Rocky desertification in Southwest China: impacts, causes, and restoration. Earth-Sci Rev 132:1-12

Johnson NC, Rowland DL, Corkidi L, Egerton-Warburton LM, Allen EB (2003) Nitrogen enrichment alters mycorrhizal allocation at five mesic to semiarid grasslands. Ecology 84:1895-1908

Johnson NC, Wilson GW, Bowker MA, Wilson JA, Miller RM (2010) Resource limitation is a driver of local adaptation in mycorrhizal symbioses. PNAS 107:2093-2098

Jumpponen A, Trowbridge J, Mandyam K, Johnson L (2005) Nitrogen enrichment causes minimal changes in arbuscular mycorrhizal colonization but shifts community composition-evidence from rDNA data. Biol Fertil Soils 41:217-224

Kiers ET, Duhamel M, Beesetty Y, Mensah JA, Franken O, Verbruggen E, Fellbaum CR, Kowalchuk GA, Hart MM, Bago A, Palmer TM, West SA, Vandenkoornhuyse P, Jansa J, Bücking H, Bücking H (2011) Reciprocal rewards stabilize cooperation in the mycorrhizal symbiosis. Science 333:880-882

Lee J, Lee S, Young JP (2008) Improved PCR primers for the detection and identification of arbuscular mycorrhizal fungi. FEMS Microbiol Ecol 65:339-349

Liang Y, He X, Chen C, Feng S, Liu L, Chen X, Zhao Z, Su Y (2015) Influence of plant communities and soil properties during natural vegetation restoration on arbuscular mycorrhizal fungal communities in a karst region. Ecol Eng 82:57-65

Liu JG, Diamond J (2005) China's environment in a globalizing world. Nature 435:1179-1186

Liu L, Gundersen P, Zhang T, Mo J (2012) Effects of phosphorus addition on soil microbial biomass and community composition in three forest types in tropical China. Soil Biol Biochem 44:31-38

Liu L, Zhang T, Gilliam FS, Gundersen P, Zhang W, Chen H, Mo J (2013) Interactive effects of nitrogen and phosphorus on soil microbial communities in a tropical forest. PLoS One 8:e61188

Liu S, Zhang W, Wang K, Pan F, Yang S, Shu S (2015) Factors controlling accumulation of soil organic carbon along vegetation succession in a typical karst region in Southwest China. Sci Total Environ 521(522):52-58

Liu M, Liu J, Chen X, Jiang C, Wu M, Li Z (2017) Shifts in bacterial and fungal diversity in a paddy soil faced with phosphorus surplus. Biol Fertil Soils 54:259-267

Majewska ML, Rola K, Stefanowicz AM, Nobis M, Błaszkowski J, Zubek S (2018) Do the impacts of alien invasive plants differ from expansive native ones? An experimental study on arbuscular mycorrhizal fungi communities. Biol Fertil Soils 54:631-643

Marklein AR, Houlton BZ (2012) Nitrogen inputs accelerate phosphorus cycling rates across a wide variety of terrestrial ecosystems. New Phytol 193:696-704

Matson PA, McDowell WH, Townsend AR, Vitousek PM (1999) The globalization of $\mathrm{N}$ deposition: ecosystem consequences in tropical environments. Biogeochemistry 46:67-83

Miller RM, Miller SP, Jastrow JD, Rivetta CB (2002) Mycorrhizal mediated feedbacks influence net carbon gain and nutrient uptake in Andropogon gerardii. New Phytol 155:149-162

Montiel-Rozas MM, López-García Á, Madejón P, Madejón E (2017) Native soil organic matter as a decisive factor to determine the arbuscular mycorrhizal fungal community structure in contaminated soils. Biol Fertil Soils 53:327-338 
Ngosong C, Gabriel E, Ruess L (2014) Collembola grazing on arbuscular mycorrhiza fungi modulates nutrient allocation in plants. Pedobiologia 57:171-179

Niinemets Ü, Kull K (2005) Co-limitation of plant primary productivity by nitrogen and phosphorus in a species-rich wooded meadow on calcareous soils. Acta Oecol 28:345-356

Nottingham AT, Hicks LC, Ccahuana AJQ, Salinas N, Bååth E, Meir P (2017) Nutrient limitations to bacterial and fungal growth during cellulose decomposition in tropical forest soils. Biol Fertil Soils 54:219-228

Oehl F, Laczko E, Oberholzer H-R, Jansa J, Egli S (2017) Diversity and biogeography of arbuscular mycorrhizal fungi in agricultural soils. Biol Fertil Soils 53:777-797

Oksanen J, Blanchet FG, Kindt R, Legendre P, Minchin PR, O'hara RB, Simpson GL, Solymos P, Stevens MHH, Wagner H (2017) Vegan: community ecology package. http://CRAN.R-project.org/package= vegan

Porter WM, Robson AD, Abbott LK (1987) Field survey of the distribution of vesicular arbuscular mycorrhizal fungi relation to soil-pH. J Appl Ecol 24:659-662

R Development Core Team (2018) R: A Language and Environment for Statistical Computing. R Foundation for Statistical Computing, Vienna, Austria. http://www.Rproject.org/

Rillig MC (2004) Arbuscular mycorrhizae and terrestrial ecosystem processes. Ecol Lett 7:740-754

Santos-Gonzalez JC, Finlay RD, Tehler A (2007) Seasonal dynamics of arbuscular mycorrhizal fungal communities in roots in a seminatural grassland. Appl Environ Microbiol 73:5613-5623

Sato K, Suyama Y, Saito M, Sugawara K (2005) A new primer for discrimination of arbuscular mycorrhizal fungi with polymerase chain reaction-denature gradient gel electrophoresis. Grassl Sci 51:179_ 181

Schöler A, Jacquiod S, Vestergaard G, Schulz S, Schloter M (2017) Analysis of soil microbial communities based on amplicon sequencing of marker genes. Biol Fertil Soils 53:485-489

Segata N, Izard J, Waldron L, Gevers D, Miropolsky L, Garrett WS, Huttenhower C (2011) Metagenomic biomarker discovery and explanation. Genome Biol 12:R60

Sun X, Su Y, Zhang Y, Wu M, Zhang Z, Pei K, Sun L, Wan S, Liang Y (2013) Diversity of arbuscular mycorrhizal fungal spore communities and its relations to plants under increased temperature and precipitation in a natural grassland. Chin Sci Bull 58:4109-4119

Sun D, Bi Q, Li K, Dai P, Yu Y, Zhou W, Lv T, Liu X, Zhu J, Zhang Q, Jin C, Lu L, Lin X (2017) Significance of temperature and water availability for soil phosphorus transformation and microbial community composition as affected by fertilizer sources. Biol Fertil Soils 54: 229-241

Sylvia DM, Neal LH (1990) Nitrogen affects the phosphorus response of VA mycorrhiza. New Phytol 115:303-310

Taylor J, Helgason T, Öpik M (2017) Molecular community ecology of arbuscular mycorrhizal fungi. The fungal community: its organization and role in the ecosystem, 4th edn. CRC Press, pp 1-26

Thomsen CN, Hart MM (2018) Using invasion theory to predict the fate of arbuscular mycorrhizal fungal inoculants. Biol Invasions 20: 2695-2706

Tian D, Niu S (2015) A global analysis of soil acidification caused by nitrogen addition. Environ Res Lett 10:024019

Tilman D (1987) Secondary succession and the pattern of plant dominance along experimental nitrogen gradients. Ecol Monogr 57:189-214

Tischer A, Werisch M, Döbbelin F, Camenzind T, Rillig MC, Potthast K, Hamer U (2015) Above- and belowground linkages of a nitrogen and phosphorus co-limited tropical mountain pasture system - responses to nutrient enrichment. Plant Soil 391:333-352

Treseder KK (2004) A meta-analysis of mycorrhizal responses to nitrogen, phosphorus, and atmospheric $\mathrm{CO}_{2}$ in field studies. New Phytol $164: 347-355$
Treseder KK, Allen MF (2002) Direct nitrogen and phosphorus limitation of arbuscular mycorrhizal fungi: a model and field test. New Phytol 155:507-515

Turrini A, Bedini A, Loor MB, Santini G, Sbrana C, Giovannetti M, Avio L (2017) Local diversity of native arbuscular mycorrhizal symbionts differentially affects growth and nutrition of three crop plant species. Biol Fertil Soils 54:203-217

Vestergaard G, Schulz S, Schöler A, Schloter M (2017) Making big data smart-how to use metagenomics to understand soil quality. Biol Fertil Soils 53:479-484

Vitousek PM, Porder S, Houlton BZ, Chadwick OA (2010) Terrestrial phosphorus limitation: mechanisms, implications, and nitrogenphosphorus interactions. Ecol Appl 20:5-15

Walker TW, Syers JK (1976) Fate of phosphorus during pedogenesis. Geoderma 15:1-19

Wang QK, Wang SL, Liu YX (2008) Responses to N and P fertilization in a young Eucalyptus dunnii plantation: microbial properties, enzyme activities and dissolved organic matter. Appl Soil Ecol 40:484-490

Wang J, Rhodes G, Huang Q, Shen Q (2018) Plant growth stages and fertilization regimes drive soil fungal community compositions in a wheat-rice rotation system. Biol Fertil Soils 54:731-742

Wei Y (2012) Molecular diversity and distribution of arbuscular mycorrhizal fungi in karst ecosystem, Southwest China. Afr J Biotechnol 11(80):14561-14568

Xie X, Weng B, Cai B, Dong Y, Yan C (2014) Effects of arbuscular mycorrhizal inoculation and phosphorus supply on the growth and nutrient uptake of Kandelia obovata (Sheue, Liu \& Yong) seedlings in autoclaved soil. Appl Soil Ecol 75:162-171

Xue C, Ryan Penton C, Zhu C, Chen H, Duan Y, Peng C, Guo S, Ling N, Shen Q (2017) Alterations in soil fungal community composition and network assemblage structure by different long-term fertilization regimes are correlated to the soil ionome. Biol Fertil Soils 54: 95-106

Yang C, Hamel C, Schellenberg MP, Perez JC, Berbara RL (2010) Diversity and functionality of arbuscular mycorrhizal fungi in three plant communities in semiarid Grasslands National Park, Canada. Microb Ecol 59:724-733

Zhang Z, Zhang J, Huang Y (2014) Effects of arbuscular mycorrhizal fungi on the drought tolerance of Cyclobalanopsis glauca seedlings under greenhouse conditions. New For 45:545-556

Zhang W, Zhao J, Pan F, Li D, Chen H, Wang K (2015) Changes in nitrogen and phosphorus limitation during secondary succession in a karst region in southwest China. Plant Soil 391:77-91

Zhang J, Wang F, Che R, Wang P, Liu H, Ji B, Cui X (2016) Precipitation shapes communities of arbuscular mycorrhizal fungi in Tibetan alpine steppe. Sci Rep 6:23488

Zheng Y, Kim YC, Tian XF, Chen L, Yang W, Gao C, Song MH, Xu XL, Guo LD (2014) Differential responses of arbuscular mycorrhizal fungi to nitrogen addition in a near pristine Tibetan alpine meadow. FEMS Microbiol Ecol 89:594-605

Zhu J, He N, Wang Q, Yuan G, Wen D, Yu G, Jia Y (2015) The composition, spatial patterns, and influencing factors of atmospheric wet nitrogen deposition in Chinese terrestrial ecosystems. Sci Total Environ 511:777-785

Zubek S, Majewska ML, Błaszkowski J, Stefanowicz AM, Nobis M, Kapusta P (2016) Invasive plants affect arbuscular mycorrhizal fungi abundance and species richness as well as the performance of native plants grown in invaded soils. Biol Fertil Soils 52:879-893

Publisher's note Springer Nature remains neutral with regard to jurisdictional claims in published maps and institutional affiliations. 